\title{
PENGGUNAAN APLIKASI QUIZIZZ SEBAGAI MEDIA PENILAIAN BERBASIS DARING DI MI AL MUQORROBIYAH
}

\author{
Nafi' Mukharomah \\ Institut Agama Islam Ngawi \\ e-mail: nafimukarromah70@gmail.com
}

\begin{abstract}
ABSTRAK
Penelitian ini bertujuan untuk mendeskripsikan bagaimana langkah-langkah Aplikasi quizizz yang dilakukan oleh guru untuk melaksanakan penilaian berbasis daring pada pembelajaran jarak jauh di Madrasah Ibtidaiyah. Penelitian ini dilakukan di Madrasah Ibtidaiyah Al Muqorrobiyah kota Ngawi pada semester ganjil Tahun ajaran 2020/2021. Penelitian ini menggunakan pendekatan kualitatif dengan jenis deskriptif. Pengumpulan data dilakukan dengan observasi secara langsung, observasi dengan menggunakan media whatsapp, wawancara, dan dokumentasi. Uji validitas data dalam penelitian ini menggunakan triangulasi teknik. Hasil penelitian ini menunjukkan bahwa guru mampu melakukan kegiatan penilaian pengetahuan siswa pada pembelajaran jarak jauh dengan memanfaatkan aplikasi quizizz. Adapun langkah-langkah dalam mengaplikasikan quizizz ini cukup mudah karena sekarang bisa diakses bagi pengguna android dimanapun dan kapanpun. Dalam pelaksanaan aplikasi quizizz ini tentu ada kelemahan-kelemahan yang muncul. Namun, kelemahan yang ada dapat diminimalisir dengan berbagai kelebihan yang dimiliki aplikasi tersebut. Salah satunya melatih siswa untuk mengerjakan soal dengan jujur dan mandiri serta guru dapat lebih cepat mengetahui hasil data statistik tentang kinerja para siswa.
\end{abstract}

Kata kunci: aplikasi quizizz, penilaian

\section{PENDAHULUAN}

Saat ini pemanfaatan TIK dalam proses pembelajaran sudah mulai digalakkan, seperti pemanfaatan internet. Pemanfaatan internet dalam proses pembelajaran salah satunya dapat dilakukan melalui penggunaan $e$-learning), $e$ learning dapat digunakan untuk menambah materi dan atau mengganti kekurangan tatap muka antara pendidik dan peserta didik yang berhalangan hadir karena suatu hal. Selain itu, dengan e-learning dimungkinkan juga dilakukan kegiatan penilaian, dimana pendidik bisa memberikan sejumlah soal atau tugas untuk dikerjakan oleh peserta didik dalam durasi waktu tertentu. ${ }^{1}$

${ }^{1}$ Ihwanah, Al. (2016). Implementasi E-Learning dalam Kegiatan Pembelajaran PGMI IAIN Sulthan Thaha Saifuddin Jambi. Jurnal Cakrawala, Vol. XI, No. 1, 12-14. 
Penilaian dapat diartikan sebagai proses mengumpulkan dan mengolah informasi yang digunakan untuk mengukur ketercapaian hasil belajar siswa. Sesuai dengan pihak yang melakukan penilaian, penilaian pembelajaran yang dilakukan oleh guru bertujuan untuk pemantauan dan pengevaluasian proses, kemajuan belajar, dan umpan balik siswa yang dilakukan secara terus menerus. Penilaian pembelajaran dapat mencakup tiga aspek yaitu aspek kognitif, afektif dan psikomotorik. Sesuai dengan standar penilaian pendidikan yang ada dalam kurikulum 2013 dijelaskan bahwa penilaian mencakup penilaian autentik, penilaian diri, penilaian berbasis portofolio, ulangan, ulangan harian, ulangan tengah semester, ulangan akhir semester, ujian tingkat kompetensi, ujian mutu tingkatan kompetensi, ujian nasional, ujian sekolah

Penilaian pada penelitian ini difokuskan penilaian formatif yang dilaksanakan secara daring. Penilaian secara daring ini dilakukan dengan menggunakan internet, yang dapat digunakan dimanapun selama memiliki jaringan internet. ${ }^{2}$ Penilaian berbasis daring ini dapat dilakukan dengan memahami betul cara menggunakan aplikasi melalui smartphone dan komputer. Dengan pemahaman yang baik, guru bisa memanfaatkan aplikasi daring ini untuk proses penilaian hasil belajar siswa.

Aplikasi-aplikasi berbasis website menyediakan sarana yang mudah dalam proses penilaian pembelajaran. ${ }^{3}$ Berbagai jenis aplikasi daring yang digunakan sebagai media penilaian contohnya yaitu, Google Form, Edmodo, Zoom, dan Quizizz. Dari beberapa aplikasi tersebut, MI Al Muqorrobiah kota Ngawi memilih menggunakan quizizz. Aplikasi ini lebih diunggulkan karena pengoperasiannya yang mudah dan bisa menjadi saran yang tepat karena terdapat banyak fitur yang dapat digunakan sebagai penilaianseperti pembuatan kuis, penilaian, dan peringkat antar siswa langsung diketahui ketika siswa selesai mengerjakan kuis yang diberikan guru.

Aplikasi quizizz ini cenderung hemat dalam peng-gunaan data internet dan

\footnotetext{
${ }^{2}$ I. F. Ahmad, (2020), “Alternative Assessment in Distance Learning in Emergencies Spread Of Coronavirus Disease ( Covid-19), ”vol. 07, no. 01, pp. 195-222.

${ }^{3}$ Fuady, M. J. (2017). Pengembangan aplikasi evaluasi pembelajaran online untuk pendidikan jarak jauh. Tekno 26(2), $\quad 148-154$.
} 
mudah digunakan oleh guru serta siswa. ${ }^{4}$ Quizizz merupakan sebuah web tool dalam bentuk tes interaktif yang digunakan dalam pembelajaran di kelas misalnya saja untuk penilaian formatif. ${ }^{5}$ Quizizz juga merupakan aplikasi berbasis game yang membawa aktivitas belajar lebih konsentrasi dan menyenangkan. ${ }^{6}$ Penggunaannya sangat mudah (tidak sekompleks membuat tes interaktif dengan software animasi), namun memiliki kualitas hasil sekelas penggunaan software animasi. Konsep dari penilaian ini adalah memanfaatkan smartphone sebagai sebagai media yang didalamnya terdapat pertanyaan dimana pertanyaan tersebut dapat dijawab dengan waktu yang telah ditentukan serta aplikasi ini dapat menampilkan skor secara langsung sehingga siswa dapat menjawab pertanyaan tersebut melalui smartphone yang dimiliki. Hal ini membuat media quizizzmenjadi media penilaian yang sangat efektif untuk mengevaluasi dan memberikan hasil secara cepat kepada guru sehingga guru bisa mengambil tindakan sesegera mungkin kepada siswa. ${ }^{7}$

Berdasarkan latar belakang di atas, penelitian difokuskan pada langkahlangkah penilaian berbasis daring menggunakan aplikasi quizizz sebagai media penilaian dan beberapa kelebihan beserta kelemahan dari aplikasi quizizz tersebut berdasarkan pengalaman guru-guru MI Al Muqorobiah.

\section{METODE PENELITIAN}

Jenis penelitian ini menggunakan deskriptif kualitatif dengan metode analitis. Penelitian kualitatif adalah prosedur penelitian yang menghasilkan data deskriptif berupa kata-kata tertulis atau lisan dari orang-orang dan prilaku yang dapat diamati. Penelitian kualitatif bertumpu pada latar belakang alamiah secara holistik, memposisikan manusia sebagai alat penelitian, melakukan analisis data

\footnotetext{
4 Sari, D. D., \& Rini, T. P. W. (2020). Bimbingan Teknis Pembelajaran Daring Menggunakan Aplikasi Quizizz Bagi Guru Sekolah Dasar Pada Masa Pandemi Covid-19. Jurnal Pendidikan Dan Pengabdian Masyarakat, 3(4), $213-217$.

${ }^{5}$ Suyasa, P. W. A., Divayana, D. G. H., Putrama, I. M., \& Damayanthi, L. P. E. (2019). Pelatihan Pembuatan Tes Interaktif Dengan Aplikasi Quizizz Bagi Paea Guru Di SMPN 2 Kediri. Seminar Nasional Pengabdian Kepada Masyarakat,4, 24-29.

${ }^{6}$ Purba, L. S. L. (2019). Peningkatan Konsentrasi Belajar Mahasiswa Melalui Pemanfaatan Evaluasi Pembelajaran Quizizz Pada Mata Kuliah Kimia Fisika I. Jurnal Dinamika Pendidikan, 12(1), 29-39.

7 Yan mei, S., Yan Ju, S., \& Adam, Z. (2018). Implementing Quizizz as Game Based Learning in the Arabic

Classroom. European Journal of Social Science Education and Research, 5(1), 194-198.
} 
secara induktif, lebih mementingkan proses daripada hasil penelitian yang dilakukan disepakati oleh peneliti dan subjek penelitian. Metode deskriptif dipilih karena penelitian yang dilakukan adalah berkaitan dengan peristiwa-peristiwa yang sedang berlangsung dan berkenaan dengan kondisi masa sekarang. Teknik pengumpulan data dan informasi diambil dengan wawancara, observasi dan menelaah sumber-sumber tertulis seperti jurnal ilmiah, buku referensi, literature, ensiklopedia, karangan ilmiah serta sumber- sumber lain yang terpercaya, baik dalam bentuk tulisan atau dalam format digital yang relevan dengan objek yang sedang diteliti dan dibangun serta dikembangkan. Sedangkan uji validitas data dalam penelitian ini menggunakan triangulasi teknik.

\section{HASIL DAN PEMBAHASAN}

Quizizz sekarang bisa diakses di playstore bagi pengguna android sehingga dalam penggunaanya lebih praktis. Ada dua pilihan untuk membuat soal dengan aplikasi quizizz. Pertama dengan membuat soal dari awal yakni dengan menu create a new quiz, dan yang kedua dengan menggunakan dan memodifikasi kuis yang telah ada di library quizizz dengan menggunakan menu find a quiz. Selain itu pengguna juga bisa mengcopy dari soal-soal yang telah ada dengan menu teleport.

Penilaian dalam bentuk tes interaktif yang dibuat dengan quizizz dapat memiliki hingga 4 pilihan jawaban termasuk jawaban yang benar. Quizizz juga memberikan data dan statistik tentang kinerja para siswa. Kita dapat melacak berapa banyak siswa yang menjawab pertanyaan yang kita buat, pertanyaan yang harus dijawab dan banyak lagi. Kita juga bias mendownload statistik ini dalam bentuk spreadsheet Excel. Fitur "pekerjaan rumah" juga tambahan fitur yang menarik. Pekerjaan rumah memungkinkan kita menetapkan tes sebagai pekerjaan rumah, dan membatasi waktu pengerjaan pekerjaan rumah tersebut hingga 2 minggu.

Berikut langkah-langkah Pembuatan quiz melalui quizizz:

1. Masuk ke www.quizizz.com lalu klik "Sign Up"

2. Pilih "sign up with email" atau "sign up with google" 


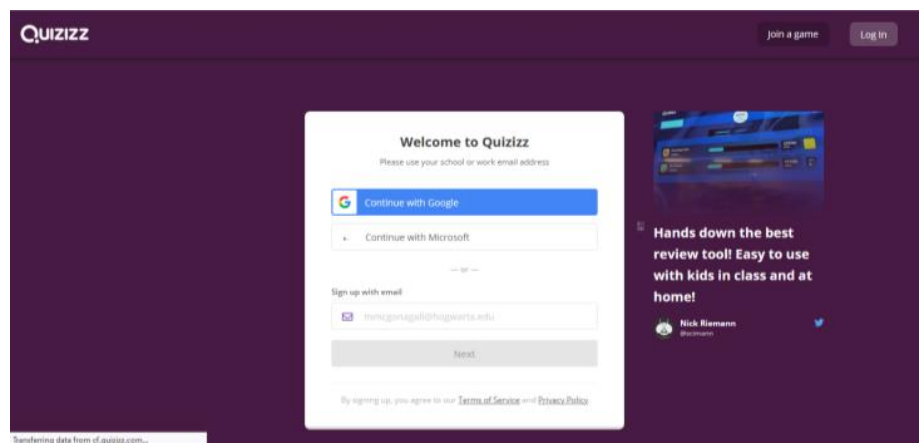

3. Klik "Teacher" jika ingin login sebagai guru

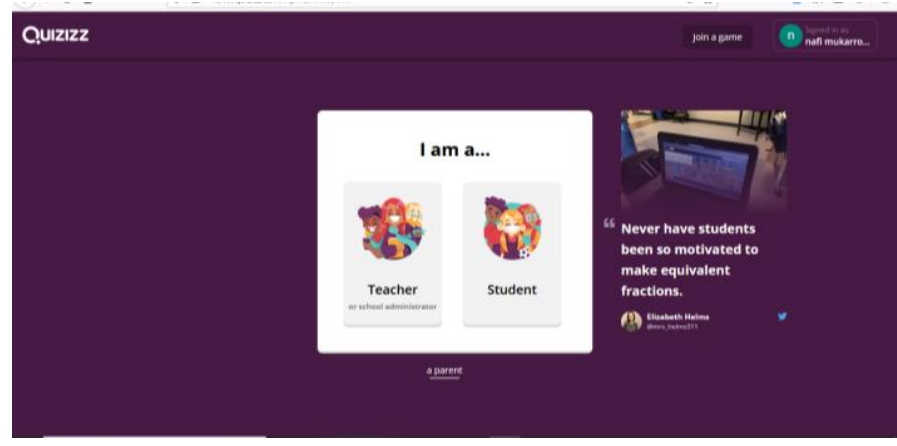

4. Masukkan identitas (Username, email, dan password) lalu Continue

5. Jika sudah masuk, buatlah kuis dengan cara mengklik "create new quiz" pada bagian kiri atas.

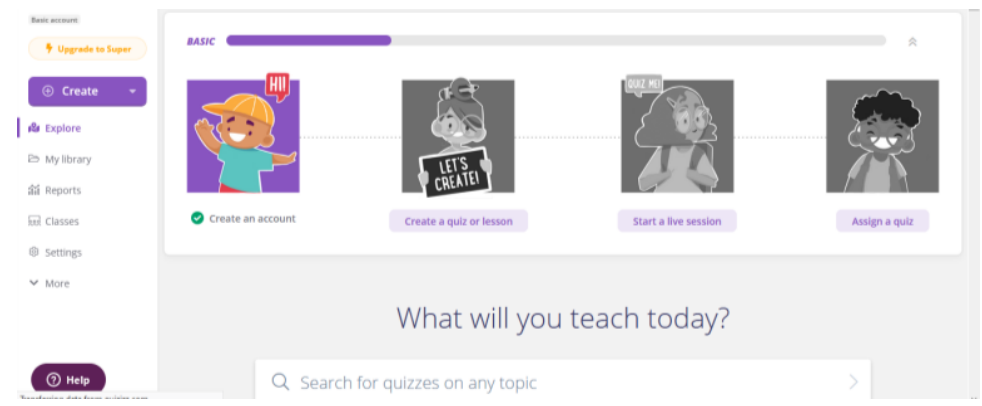

6. Akan muncul tampilan Let's create a quiz : Masukkan nama kuis, bahasa lalu klik "save"

7. Akan muncul tampilan selanjutnya lalu klik "Create new question"

8. Masukkan pertanyaan pada kolom "Write your question here" lalu masukkan opsi jawaban (jika menggunakan pilihan ganda) pada kolom "Answer option 1, answer option 2, dan seterusnya"

9. Beri centang pada bagian kolom jawaban yang benar, atur durasi 
pengerjaan dalam satu soal, lalu klik "save"

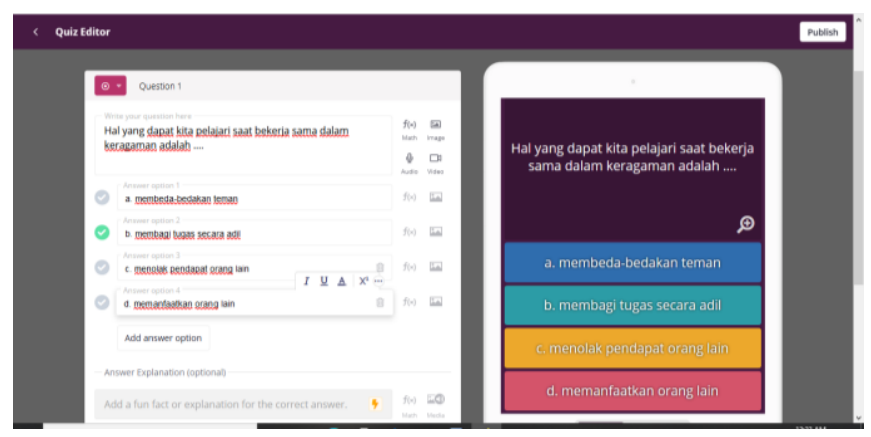

10. Jika sudah menulis semua kuis, klik "Finish Quiz"

11. Maka akan muncul tampilan Quiz Detail (atur kelas berapa kuis itu ingin ditujukan dan mata pelajaran apa yang digunakan) lalu klik "save details"

12. Akan muncul tampilan selanjutnya, pilih "Homework" jika ingin digunakan sebagai PR dan pilih "Play Live" jika ingin digunakan sebagai mulai sekarang.

13. Masukkan deadline pengerjaan (atur tanggal dan jam) lalu klik "Procced" 14. Akan muncul tampilan selanjutnya yaitu kode yang digunakan untuk masuk dalam pengerjaan kuis.

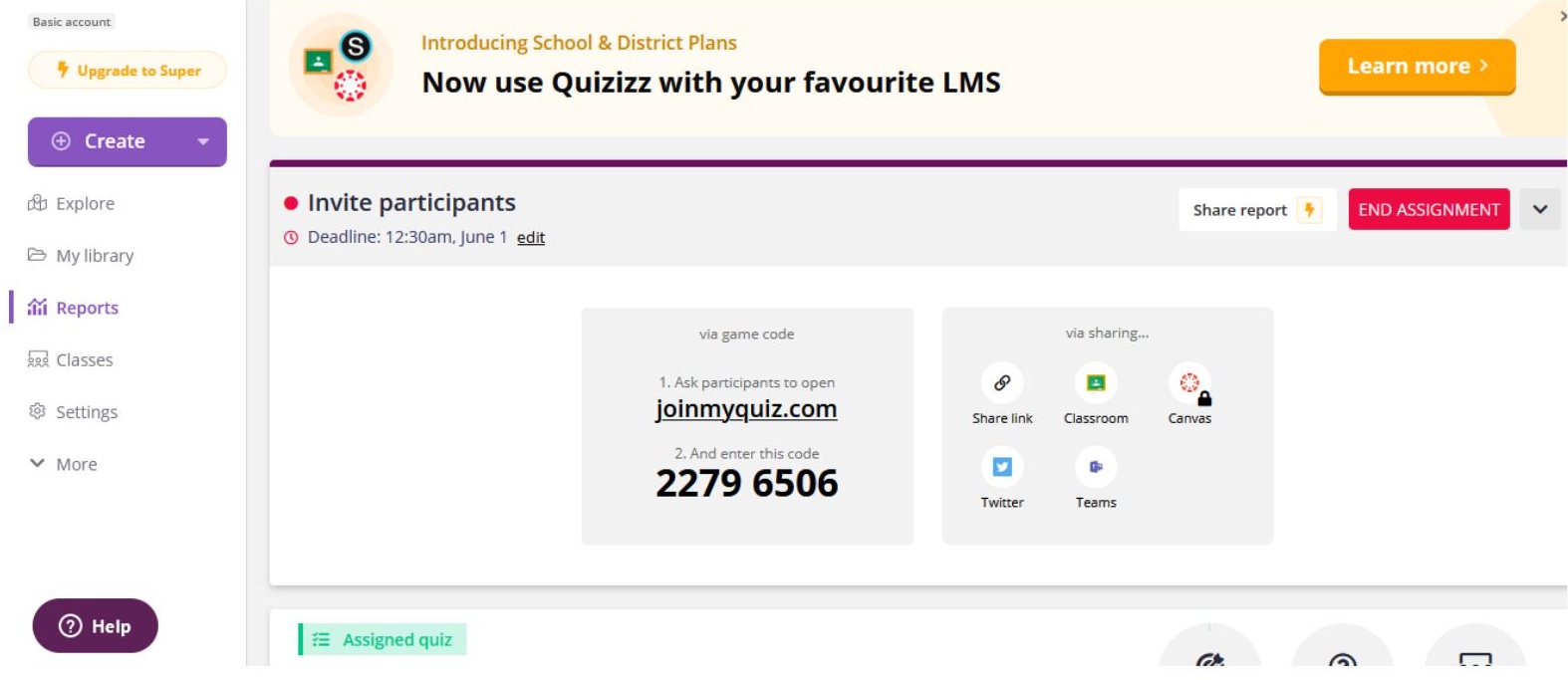

\section{Cara mengerjakan kuis :}

15. Siswa membuka link https://join.quizizz.com

16. Siswa memasukkan 6 digit kode yang diberikan oleh guru lalu klik 


\section{"Proceed"}

17. Siswa memasukkan nama mereka masing-masing lalu klik "start"

18. Siswa mengerjakan kuis tersebut dengan waktu setiap soal, misal 20 detik (sesuai dengan aturan guru)

\section{Keterangan kuis :}

19. Setiap siswa selesai menjawab pertanyaan dengan benar maka akan muncul berapa point yang didapatkan dalam satu soal dan juga mendapat ranking berapa dalam menjawab soal tersebut.

20. Jika siswa menjawab salah pertanyaan tersebut, maka akan muncul jawaban yang benar/ correct.

21. Jika selesai mengerjakan kuis, pada akhir kuis akan ada tampilan Review Question untuk melihat kembali jawaban yang kita pilih.

22. Dalam pengerjaan kuis, setiap siswa mendapatkan daftar pertanyaan yang berbeda dengan siswa lainnya karena kuis tersebut dibuat dalam bentuk Homework/PR sehingga daftar soalnya diacak dan setiap siswa, soal yang muncul berbeda-beda.

Quizizz telah dilakukan oleh peneliti untuk membangun semangat dan meningkatkan motivasi belajar siswa, hasil wawancara dan pengamatan, mereka para siswa menyukai bentuk penilaian seperti yang ditampilkan oleh quizizz karena hasil yang dapat dilihat dan para siswa dapat lebih mengetahui dimana letak kesalahan mereka. Selain itu, aplikasi quizizz dapat menampilkan soal dalam bentuk gambar dan suara.

Hanya saja berdasarkan wawancara dengan para guru, kelemahan dari aplikasi ini adalah tidak dapat melihat kemampuan siswa yang sebenarnya, jika menggunakan bentuk kuis pilihan ganda. Soal-soal cenderung untuk mengungkapkan ingatan dan daya pengenalan kembali saja, oleh karena itu guru sedikit kesulitan untuk mengukur proses mental yang lebih tinggi tiap siswa. Banyak kesempatan untuk main untung-ungtungan karena waktu pengerjaan tiap soal dibatasi, akhirnya siswa yang merasa kesulitan hanya asal jawab.

Namun dengan kelemahan yang ada, ternyata kelebihan soal bentuk objektif pun ada dan akan sangat membantu dalam menutupi kelemahan yang ada, yaitu: 
dapat mewakili isi yang lebih representatif, luas bahan materinya, obyektif, menghindari unsur subjektif, guru lebih mudah dan cepat cara memeriksanya, pemeriksaan juga dapat diserahkan kepada orang lain, setiap peserta didik yang menjawab pertanyaan dengan benar, maka akan muncul skor yang didapat dalam satu soal dan juga mendapat peringkat dalam menjawab soal tersebut, apabila peserta didik menjawab pertanyaan salah, maka jawaban yang benar akan muncul sehingga peserta didik dapat melakukan review atas jawaban yang telah dipilih sebelumnya. Selain itu setiap peserta didik akan mendapatkan pertanyaan yang berbeda dengan peserta didik lain dikarenakan soal yang muncul akan diacak, sehingga meminimalisir kemungkinan peserta didik untuk saling tukar jawab- an atau mencontek, batas waktu pengerjaan setiap soal juga bisa disesuaikan dengan tingkat kesukaran dari masing-masing pertanyaan.

Kelebihan dari aplikasi Quizizz tidak hanya menyediakan guru untuk membuat soal pilihan ganda (multiple choice) melainkan ada tipe soal kotak centang (checkbox), isi bagian yang kosong (Fill-in-the blank), pemilihan (poll), dan terbuka- berakhir (open ended). Selain itu Quizizz juga memberikan rekapan secara statistik tentang kinerja peserta didik. Kita bisa melacak berapa banyak peserta didik menjawab soal dengan benar, menjawab dengan salah, dan banyak lagi. Peserta didik juga bisa melihat hasil kinerjanya secara langsung dan dapat mengetahui peringkat yang diperoleh ketika mengerjakan soal di Quizizz. Hal tersebut dapat memotivasi peserta didik untuk bersaing secara kompetitif melalui fitur "Play Live" atau mengerjakan soal secara bersama-sama dengan peserta didik yang lain dalam waktu yang bersamaan. Selain fitur play live juga tersedia fitur assign Hw dimana memungkinkan peserta didik untuk mengerjakan soal yang telah dibuat oleh guru dengan menetapkan tes sebagai pekerjaan rumah yang dibatasi waktu pengerjaannya.

Harapannya, dengan adanya aplikasi online seperti Quizizz ini dapat menjadikan pembelajaran dan penilaian menjadi lebih mudah dan menyenangkan. Sehingga tujuan dari pendidikan akan tercapai jika pengajar dan para siswa memiliki semangat dan saling mendukung antara yang satu dengan yang lainnya. 


\section{SIMPULAN}

Aplikasi kuis online Quizizz dapat digunakan oleh para pengajar untuk melihat sejauh mana siswa dalam belajar. Penggunaan yang mudah dan hasil yang cepat dalam proses penilaiannya menjadikan aplikasi ini layak digunakan sebagai media penialaian berbasis daring, sehingga siswa memiliki minat dan motivasi untuk belajar dan mengerjakan soal evaluasi secara jujur dan mandiri. Dalam pelaksanaan aplikasi quizizz ini tentu ada kelemahan-kelemahan yang muncul. Namun, kelemahan yang ada dapat diminimalisir dengan berbagai kelebihan yang dimiliki aplikasi tersebut.

\section{DAFTAR PUSTAKA}

Ihwanah, Al. (2016). Implementasi E-Learning dalam Kegiatan Pembelajaran PGMI IAIN Sulthan Thaha Saifuddin Jambi. Jurnal Cakrawala, Vol. XI, No. 1.

F. Ahmad, (2020), “Alternative Assessment in Distance Learning in Emergencies Spread Of Coronavirus Disease ( Covid-19)," vol. 07, no. 01.

Fuady, M. J. (2017). Pengembangan aplikasi evaluasi pembelajaran online untuk pendidikan jarak jauh. Tekno, 26(2).

Sari, D. D., \& Rini, T. P. W. (2020). Bimbingan Teknis Pembelajaran Daring Menggunakan Aplikasi Quizizz Bagi Guru Sekolah Dasar Pada Masa Pandemi Covid-19. Jurnal Pendidikan Dan Pengabdian Masyarakat, 3(4).

Suyasa, P. W. A., Divayana, D. G. H., Putrama, I. M., \& Damayanthi, L. P. E. (2019). Pelatihan Pembuatan Tes Interaktif Dengan Aplikasi Quizizz Bagi Paea Guru Di SMPN 2 Kediri. Seminar Nasional Pengabdian Kepada Masyarakat.

Purba, L. S. L. (2019). Peningkatan Konsentrasi Belajar Mahasiswa Melalui Pemanfaatan Evaluasi Pembelajaran Quizizz Pada Mata Kuliah Kimia Fisika I. Jurnal Dinamika Pendidikan, 12(1).

Yan mei, S., Yan Ju, S., \& Adam, Z. (2018). Implementing Quizizz as Game Based Learning in the Arabic Classroom. European Journal of Social Science Education and Research, 5(1). 